\title{
MOF Encapsulation of Ru Olefin Metathesis Catalysts to Block Catalyst Decomposition
}

\author{
Gerard Pareras ${ }^{1}\left(\mathbb{D}\right.$, Davide Tiana ${ }^{1}(\mathbb{D})$ and Albert Poater ${ }^{1,2, *(\mathbb{D})}$ \\ 1 School of Chemistry, University College Cork, College Road, Cork, Ireland; gpareras@gmail.com (G.P.); \\ davide.tiana@ucc.ie (D.T.) \\ 2 Institut de Química Computacional i Catàlisi, Departament de Química, Universitat de Girona, c/ Ma Aurèlia \\ Capmany 69, 17003 Girona, Catalonia, Spain \\ * Correspondence: albert.poater@udg.edu; Tel.: +34-972419403
}

Received: 30 May 2020; Accepted: 16 June 2020; Published: 18 June 2020

\begin{abstract}
In the present work, a catalyst variation of the second-generation Hoveyda-Grubbs catalyst, particularly the ammonium-tagged Ru-alkylidene metathesis catalyst AquaMet ${ }^{\mathrm{TM}}$, is under study, not simply to increase the efficiency in olefin metathesis but also the solubility in polar solvents. Moreover, this ionic catalyst was combined with the metal organic framework (MOF) (Cr)MIL-101- $\mathrm{SO}_{3}{ }^{-}(\mathrm{Na} \cdot 15-\mathrm{crown}-5)^{+}$. We started from the experimental results by Grela et al., who increased the performance when the ruthenium catalyst was confined inside the cavities of the MOF, achieving non-covalent interactions between both moieties. Here, using density functional theory (DFT) calculations, the role of the ammonium N-heterocyclic carbene (NHC) tagged and the confinement effects are checked. The kinetics are used to compare reaction profiles, whereas SambVca steric maps and NCI plots are used to characterize the role of the MOF structurally and electronically.
\end{abstract}

Keywords: MOF; ruthenium; olefin metathesis; computational; ammonium-tagged

\section{Introduction}

Olefin metathesis by Ru-based catalysts certainly has a promising position for finding new applications for industry [1-3]. The basic transformations of raw materials in the oil refinery, polymer chemistry, as well as the fine chemical synthesis in the pharmaceutical industry, are the main examples of the industrial-level potential of this transition metal-catalysed reaction [4-7]. Basically, the goal is to obtain double $\mathrm{C}-\mathrm{C}$ bonds from other existing ones. Although it may seem like an easy redistribution of C-C double bonds [8,9], a thorough understanding of its mechanism, as well as any unwanted parallel processes that could decrease its efficiency are necessary [10-13]. If that were not enough, apart from the activity, then an additional effort is needed to control the chemo-, regio- and stereoselectivity of the metathesis [14-16].

To improve the performance of olefin metathesis catalysts, attempts to anchor them by means of their ionization led to ammonium-tagged Ru-alkylidene metathesis catalysts [17-19]. This represents the addition of the Brönsted acid nature in the framework of olefin metathesis [20-22]. Actually, depending on the generation of olefin metathesis catalysts, results were significantly different. The first generation of catalysts has the ammonium group installed in the benzylidene ligand, giving relatively pure metathesis products. Moreover, they are used in polar solvents including water [23] or immobilised on various supports. On the other hand, for the second generation, catalysts tagged in the N-heterocyclic carbene (NHC) ligand became more stable, and consequently the metal contamination levels decreased. Promising for future industrial purposes, the non-dissociating ligand tagged systems were successfully immobilised on zeolites and metal organic frameworks (MOFs). This allows their use in batch and in continuous flow conditions. 
Furthermore, to increase selectivity, a combination of olefin metathesis catalysts with MOFs by Grela and co-workers [24] imposed a special confinement [25]. Particularly, the MOF (Cr)MIL-101- $\mathrm{SO}_{3}{ }^{-}$ $\left(\mathrm{Na} \cdot 15-\right.$ crown-5) ${ }^{+}$with the catalyst AquaMet ${ }^{\mathrm{TM}}$ created a non-covalent immobilization in the MOF [26-28].

Although we should have a good knowledge of the mechanism of olefin metathesis by Ru-based catalysts, both experimentally [29-43] and theoretically [44-58], as well as the potential decomposition reactions [59-65] or non-productive (or degenerate) metathesis [66,67], we have not mastered them all, despite attempts to improve them $[68,69]$. In this study, confining the catalyst inside the cavities of a MOF can improve the performance (see Figure 1), simply by reducing any undesired reaction due to the interaction between two catalytic moieties, leading to the formation of Ru-H hydrides via bimolecular decomposition [70].

This study, using density functional theory (DFT) calculations, aims to unveil the role of the NHC-tagged catalyst AquaMet, and type of the confinement of the ruthenium catalyst inside a cavity of the MOF (Cr)MIL-101-SO ${ }_{3}^{-}\left(\mathrm{Na} \cdot 15-\right.$ crown-5) ${ }^{+}$. The X-ray structure of the MOF included in Figure $1 \mathrm{a}$ was obtained from Grela and Chmielewski [26], and the model of the MOF (Figure 1b) consists of a Cr-trimer linked to a six 1,4-benzenedicarboxylic acid (bdc) ligand.

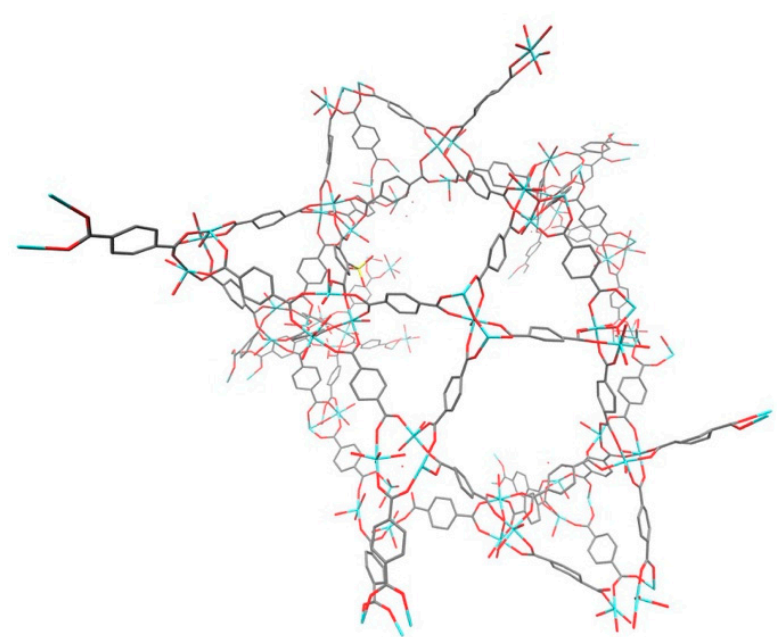

(a)

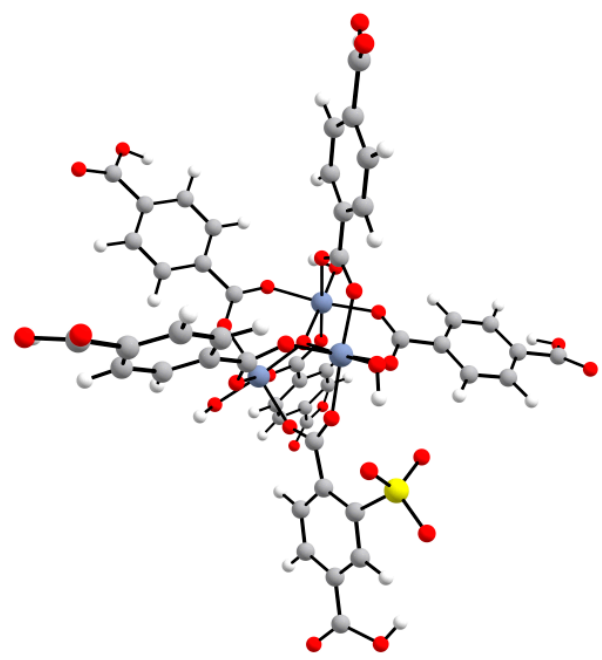

(b)

Figure 1. (a) Snapshot of the X-ray for the metal organic framework (MOF) (Cr)MIL-101-SO ${ }^{-}$ $\left(\mathrm{Na} \cdot 15-\right.$ crown-5) ${ }^{+}[26]$, and (b) with the addition of the catalyst AquaMet ${ }^{\mathrm{TM}}$ as part of the MOF.

\section{Results and Discussion}

The study started with the reaction profile with ethylene of the initiation for the neutral Hoveyda-type catalyst (HOV) displayed in Scheme 1a, for the sake of comparison with the ammonium-tagged ones (Scheme 1b,c). The first step of the reaction profile can be dissociative or concerted [71], especially considering the small nature of the olefin chosen. Figure 2 confirms that the $18 \mathrm{e}$ species is too sterically demanding and the system kinetically prefers $2.1 \mathrm{kcal} / \mathrm{mol}$ to go first via the 14e species. We applied the method of Martin and co-workers [72] to delicately deal with the overestimation of the entropy when joining several chemical moieties, and proved olefin metathesis for the activation of Ru-based olefin metathesis catalysts [73]. Otherwise, this energy difference would enlarge up to $5.5 \mathrm{kcal} / \mathrm{mol}$ without this correction, confirming the dissociative nature of the first step for HOV. Next, from the latter 14e species, the entering olefin bonds to ruthenium overcoming an energy barrier of $3.4 \mathrm{kcal} / \mathrm{mol}$. The corresponding coordination intermediate Ci1 is rather unstable and by overcoming an energy barrier of just only $2.5 \mathrm{kcal} / \mathrm{mol}$ the Mcy is reached. This latter metallacycle is interestingly rather unstable, placed $16.7 \mathrm{kcal} / \mathrm{mol}$ above the initial catalyst. The opening of the metallacycle is $4.3 \mathrm{kcal} / \mathrm{mol}$ more expensive than the previous closure, and leads to 
a second coordination intermediate Ci2, also less stable, by $7.3 \mathrm{kcal} / \mathrm{mol}$ than the first. Finally, via a barrierless process the olefin is released. However, there is probably a more energetic step in-between that consists of a nearly $90^{\circ}$ rotation of the product olefin. Even though the rate determining step (rds) were supposed to be the olefin release according to Solans-Monfort and co-workers [74], the opening of the metallacycle would be here.

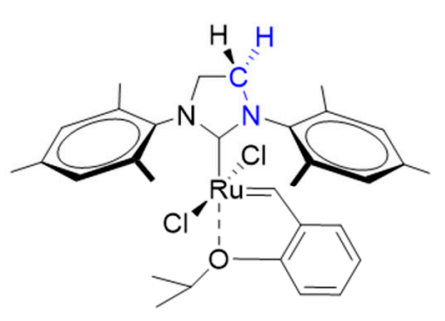

(a)

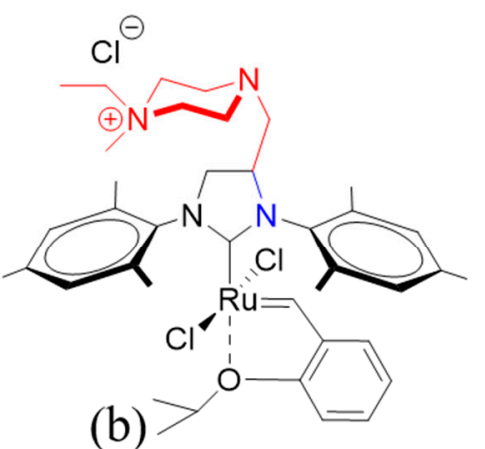

(b)

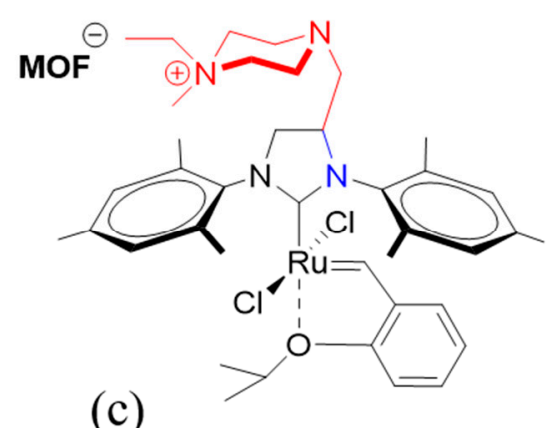

(c)

Scheme 1. Three-dimensional (3D) Lewis structure of the olefin metathesis catalysts studied: (a) Hoveyda-type catalyst (HOV); (b) AquaMet ${ }^{\mathrm{TM}}$; (c) MOF-AquaMet ${ }^{\mathrm{TM}}$.

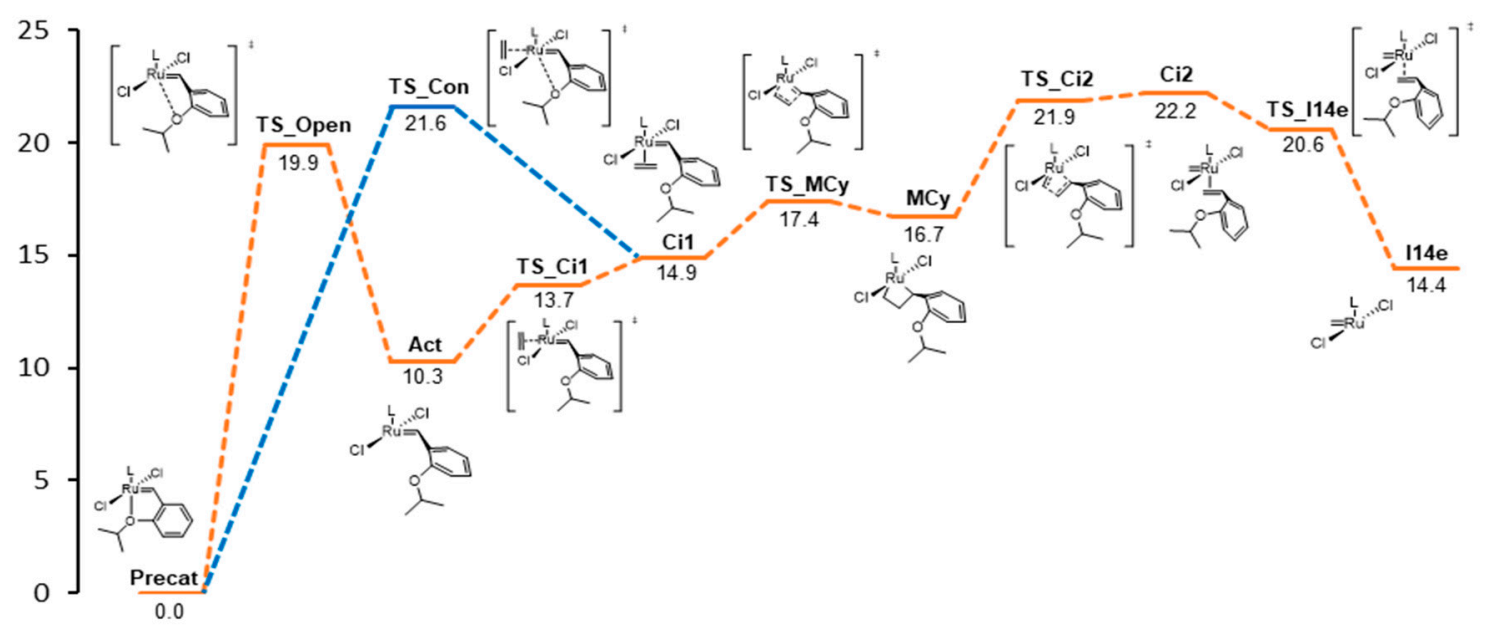

Figure 2. Calculated reaction profile for the initiation of the neutral HOV catalyst (free energies in $\mathrm{kcal} / \mathrm{mol}$ ). Blue lines correspond the concerted bonding of ethylene together with the Ru-O bond cleavage (free energies in solvent given in $\mathrm{kcal} / \mathrm{mol}$ ).

As shown in Scheme $1 \mathrm{~b}$, the HOV was combined with a chloride counteranion, since the substitution of one hydrogen of the backbone of the NHC ligand by a cationic chain led to the neutral ammonium-tagged AquaMet ${ }^{\mathrm{TM}}$. For the sake of consistency, the cationic AquaMet ${ }^{\mathrm{TM}+}$ was also studied (i.e., an ammonium NHC-tagged olefin metathesis catalyst). Moreover, it is its cationic part that deals with the MOF. The comparison of the results displayed in Figure 2, with respect to the homologous ammonium NHC-tagged olefin metathesis catalyst, unveil minimal energy differences [75]. Table 1 confirms that there are insignificant differences not only between the neutral HOV and AquaMet ${ }^{\mathrm{TM}}$, but also with respect to the charged AquaMet ${ }^{\mathrm{TM}+}$. To point out, the rds goes down by 2.0 and $1.5 \mathrm{kcal} / \mathrm{mol}$ for AquaMet ${ }^{\mathrm{TM}+}$ and AquaMet ${ }^{\mathrm{TM}}$, respectively (see Figure 3). Thus, kinetically speaking, the ammonium-tagged catalysts should perform slightly better, whereas the thermodynamics are quite similar. On the other hand, the concerted transition state is located even further, and the energy difference with respect to the initial Ru-O bond cleavage rises up from $1.7 \mathrm{kcal} / \mathrm{mol}$ for $\mathrm{HOV}$ to 8.3 and $9.0 \mathrm{kcal} / \mathrm{mol}$ for AquaMet ${ }^{\mathrm{TM}+}$ and AquaMet ${ }^{\mathrm{TM}}$, respectively. 
Table 1. Relative energies of the reaction profile of the initiation in olefin metathesis with ethylene as a substrate for the Hoveyda catalysts (HOV), with the tagged N-heterocyclic carbene (NHC) ligand, including the chloride counteranion (AquaMet ${ }^{\mathrm{TM}}$ ) or not $\left(\right.$ AquaMet $^{\mathrm{TM}+}$ ). Energy values in kcal/mol.

\begin{tabular}{cccccccccccc}
\hline Catalyst & Precat & TS_open & Act & TS_Ci1 & Ci1 & TS_MCy & MCy & TS_Ci2 & Ci2 & TS_I14e & I14e \\
\hline HOV & 0.0 & 19.9 & 10.3 & 13.7 & 14.9 & 17.4 & 16.7 & 21.9 & 22.2 & 20.6 & 14.4 \\
AquaMet $^{\mathrm{TM}+}$ & 0.0 & 15.8 & 9.0 & 12.5 & 15.0 & 16.6 & 16.1 & 19.9 & 19.0 & 19.4 & 13.4 \\
AquaMet $^{\mathrm{TM}}$ & 0.0 & 15.4 & 10.9 & 13.7 & 14.2 & 17.8 & 16.4 & 20.4 & 21.7 & 19.9 & 14.0 \\
\hline
\end{tabular}
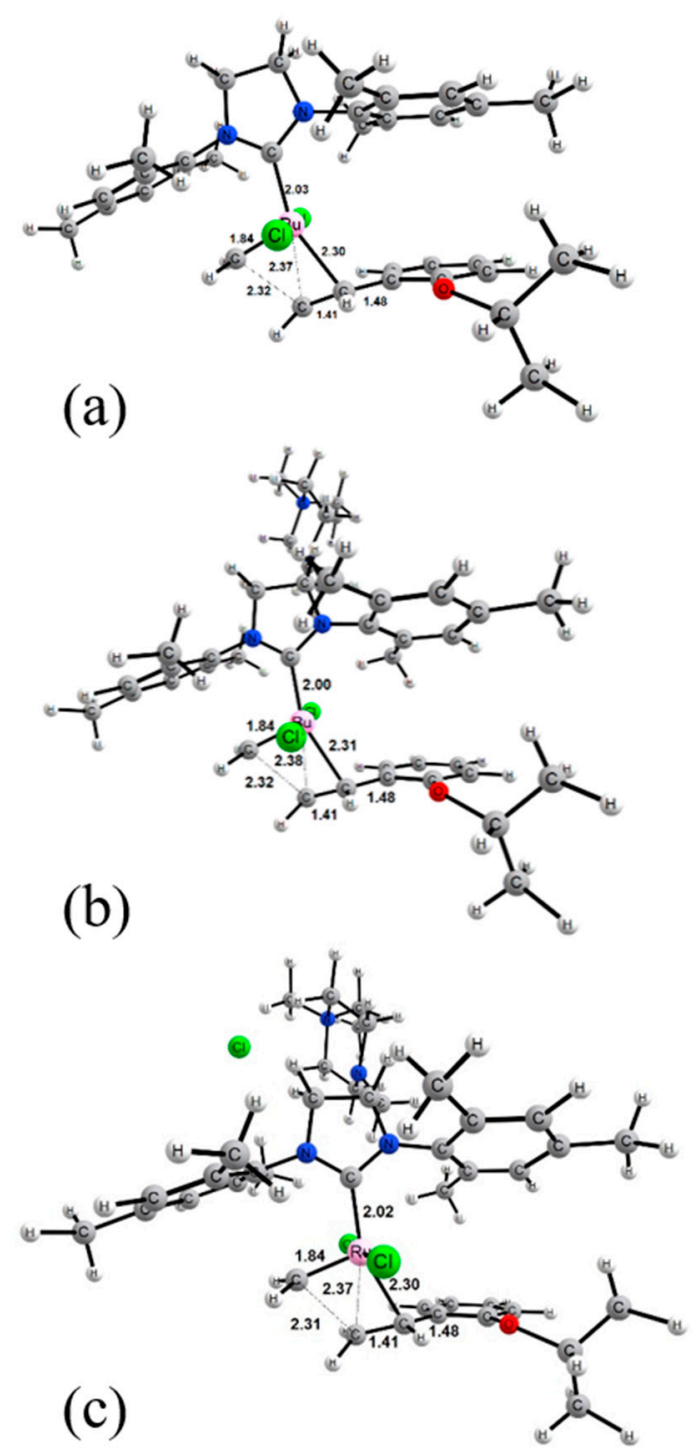

Figure 3. Transition state TS_Ci2 of the opening of the metallacycle for (a) HOV, (b) AquaMet ${ }^{\mathrm{TM}+}$ and (c) AquaMet ${ }^{\mathrm{TM}}$ (selected distances in $\AA$ ).

Table 2 demonstrates that the key bonds are not that different holding the ammonium-tagged ligand or not. The ruthenium with the ylidene group bonds similarly. In addition, the Ru-O bond is slightly weaker (elongated by $0.007 \AA$ ) and translates into a decrease of the energy barrier of the $\mathrm{Ru}-\mathrm{O}$ bond cleavage by 4.1 and $4.5 \mathrm{kcal} / \mathrm{mol}$ for AquaMet ${ }^{\mathrm{TM}+}$ and AquaMet $^{\mathrm{TM}}$, respectively. Thus, the presence of the ammonium-tagged ligand facilitates this bond cleavage. 
Table 2. Main distances for catalysts $\mathrm{HOV}$, AquaMet ${ }^{\mathrm{TM}}$ and MOF-AquaMet ${ }^{\mathrm{TM}}$ (in $\AA$ ).

\begin{tabular}{|c|c|c|c|c|c|c|c|}
\hline Catalyst & Bond & Precat & Act & Ci1 & МCy & $\mathrm{Ci} 2$ & I14e \\
\hline \multirow[t]{4}{*}{$\mathrm{HOV}$} & $\mathrm{Ru}=\mathrm{C}_{\text {ylidene }(1)}$ & 1.848 & 1.846 & 1.873 & 2.035 & 2.241 & - \\
\hline & $\mathrm{Ru}=\mathrm{C}_{\text {ylidene }(2)}$ & - & - & 2.276 & 1.980 & 1.814 & 1.809 \\
\hline & $\mathrm{Ru}-\mathrm{C}_{\mathrm{NHC}}$ & 1.965 & 1.927 & 2.033 & 2.016 & 2.076 & 1.933 \\
\hline & $\mathrm{Ru}-\mathrm{O}$ & 2.304 & - & - & - & - & - \\
\hline \multirow[t]{4}{*}{ AquaMet $^{\mathrm{TM}+}$} & $\mathrm{Ru}=\mathrm{C}_{\text {ylidene }}(1)$ & 1.850 & 1.851 & 1.877 & 2.042 & 2.283 & - \\
\hline & $\mathrm{Ru}=\mathrm{C}_{\text {ylidene }}(2)$ & - & - & 2.291 & 1.981 & 1.824 & 1.809 \\
\hline & $\mathrm{Ru}-\mathrm{C}_{\mathrm{NHC}}$ & 1.953 & 1.916 & 2.014 & 2.007 & 1.981 & 1.917 \\
\hline & $\mathrm{Ru}-\mathrm{O}$ & 2.296 & - & - & - & - & - \\
\hline \multirow[t]{4}{*}{ AquaMet $^{\mathrm{TM}}$} & $\mathrm{Ru}=\mathrm{C}_{\text {ylidene }}(1)$ & 1.848 & 1.845 & 1.871 & 2.033 & 2.240 & - \\
\hline & $\mathrm{Ru}=\mathrm{C}_{\text {ylidene }(2)}$ & - & - & 2.275 & 1.979 & 1.814 & 1.809 \\
\hline & $\mathrm{Ru}-\mathrm{C}_{\mathrm{NHC}}$ & 1.966 & 1.935 & 2.034 & 2.015 & 2.079 & 1.939 \\
\hline & $\mathrm{Ru}-\mathrm{O}$ & 2.311 & - & - & - & - & - \\
\hline
\end{tabular}

Moving to electronics, conceptual DFT was considered to find out if the nature of the studied olefin metathesis catalysts allows any differentiation. Among definitions, electrophilicity and chemical hardness are the parameters that could fit here. The electrophilicity of the catalysts was evaluated by means of the Parr electrophilicity index, using Equation (1) [76], where $\mu$ and $\eta$ are the chemical potential and the molecular hardness, respectively. Using DFT [77], $\mu$ and $\eta$ for an N-electron system with total electronic energy $\mathrm{E}$ and subject to an external potential are defined as the first and second derivatives of the energy with respect to $\mathrm{N}$ at a fixed external potential. By Koopmans' theorem [78], $\mu$ and $\eta$ can be approximated with the finite difference formulas of Equation (2), where $\varepsilon_{H}$ and $\varepsilon_{L}$ are the energies of the highest occupied molecular orbital (HOMO) and the lowest unoccupied molecular orbital (LUMO), respectively.

$$
\begin{gathered}
\omega=\frac{\mu^{2}}{2 \eta} \\
\mu \cong \frac{1}{2}\left(\varepsilon_{L}+\varepsilon_{H}\right) \text { and } \eta \cong \frac{1}{2}\left(\varepsilon_{L}-\varepsilon_{H}\right)
\end{gathered}
$$

Regarding the results in Table 3, and focusing on chemical hardness, the addition of the ammonium moiety is demonstrated as sterile, whereas electrophilicity shows subtle differentiating effects. Although electrophilicity is similar for AquaMet ${ }^{\mathrm{TM}}$, it is worth noting the almost doubly positive value for the cationic part of it. Since with the MOF the interaction occurs from this fragment, although it is partially stabilized with the negative charge of a sulfonated group, here the electrophilicity is more incipient for this cationic fragment. This trend is maintained for both 14e species, Act and I14e.

Table 3. Conceptual density functional theory (DFT) analysis ( $\mu=$ chemical potential, $\eta=$ chemical

\begin{tabular}{|c|c|c|c|c|c|c|c|c|c|c|}
\hline \multirow[t]{2}{*}{ Catalyst } & & \multicolumn{3}{|c|}{ Precat } & \multicolumn{3}{|c|}{ Act } & \multicolumn{3}{|c|}{ I14e } \\
\hline & & $\mu$ & $\eta$ & $\varepsilon$ & $\mu$ & $\eta$ & $\varepsilon$ & $\mu$ & $\eta$ & $\varepsilon$ \\
\hline \multirow[t]{2}{*}{$\mathrm{HOV}$} & Gas & -0.125 & 0.059 & 0.134 & -0.129 & 0.069 & 0.120 & -0.133 & 0.079 & 0.111 \\
\hline & Solvent & -0.139 & 0.117 & 0.082 & -0.141 & 0.124 & 0.080 & -0.142 & 0.142 & 0.071 \\
\hline \multirow[t]{2}{*}{ AquaMet ${ }^{\mathrm{TM}+}$} & Gas & -0.184 & 0.064 & 0.265 & -0.187 & 0.072 & 0.243 & -0.197 & 0.084 & 0.232 \\
\hline & Solvent & -0.157 & 0.119 & 0.103 & -0.158 & 0.124 & 0.101 & -0.161 & 0.145 & 0.090 \\
\hline \multirow[t]{2}{*}{ AquaMet $^{\mathrm{TM}}$} & Gas & -0.115 & 0.057 & 0.116 & -0.115 & 0.066 & 0.099 & -0.118 & 0.076 & 0.091 \\
\hline & Solvent & -0.135 & 0.116 & 0.078 & -0.134 & 0.123 & 0.073 & -0.136 & 0.141 & 0.065 \\
\hline
\end{tabular}
hardness, $\varepsilon=$ Parr electrophicity; in a.u.) for Precat, Act and I14e.

The positive charge of the cationic ammonium species remains on the ammonium-tagged ending group, whereas the first sphere containing the atoms around the metal centre is not significantly affected. Table 4 gathers all the information related to natural bond orbital (NBO) charges. The charge on the ruthenium is the same for the first $14 \mathrm{e}$ species Act, but interestingly for the initial precatalytic 
structure Precat, HOV presents a less positive charge; thus, it is less prone to react with potential olefins, but the difference is just $0.003 \mathrm{e}^{-}$.

Table 4. Natural bond orbital (NBO) charge analysis on the metal, oxygen, two $\mathrm{C}_{\mathrm{ylidene}}, \mathrm{C}_{\mathrm{NHC}}$ and two chlorides (in $\mathrm{e}^{-}$).

\begin{tabular}{|c|c|c|c|c|c|c|c|}
\hline Catalyst & Atom & Precat & Act & Ci1 & МCy & $\mathrm{Ci} 2$ & I14e \\
\hline \multirow[t]{7}{*}{$\mathrm{HOV}$} & $\mathrm{Ru}$ & -0.253 & -0.157 & -0.337 & -0.269 & -0.283 & -0.178 \\
\hline & $\mathrm{Ru}=\mathrm{C}_{\text {ylidene }}(1)$ & -0.001 & -0.024 & 0.051 & -0.164 & -0.443 & - \\
\hline & $\mathrm{Ru}=\mathrm{C}_{\text {ylidene }}(2)$ & - & - & -0.426 & -0.333 & -0.147 & -0.205 \\
\hline & $\mathrm{C}_{\mathrm{NHC}}$ & 0.487 & 0.505 & 0.458 & 0.481 & 0.462 & - \\
\hline & $\mathrm{O}$ & -0.475 & -0.531 & -0.529 & -0.541 & -0.544 & - \\
\hline & $\mathrm{Cl}_{1}$ & -0.268 & -0.253 & -0.296 & -0.308 & -0.303 & - \\
\hline & $\mathrm{Cl}_{2}$ & -0.269 & -0.264 & -0.288 & -0.306 & -0.298 & - \\
\hline \multirow[t]{7}{*}{ AquaMet $^{\mathrm{TM}+}$} & $\mathrm{Ru}$ & -0.253 & -0.156 & -0.342 & -0.274 & -0.342 & -0.174 \\
\hline & $\mathrm{Ru}=\mathrm{C}_{\text {ylidene }(1)}$ & 0.002 & -0.020 & 0.050 & -0.161 & -0.465 & - \\
\hline & $\mathrm{Ru}=\mathrm{C}_{\text {ylidene }}(2)$ & - & - & -0.424 & -0.328 & -0.133 & -0.197 \\
\hline & $\mathrm{C}_{\mathrm{NHC}}$ & 0.485 & 0.502 & 0.464 & 0.482 & 0.473 & - \\
\hline & $\mathrm{O}$ & -0.476 & -0.533 & -0.531 & -0.545 & -0.537 & - \\
\hline & $\mathrm{Cl}_{1}$ & -0.253 & -0.240 & -0.291 & -0.308 & -0.294 & - \\
\hline & $\mathrm{Cl}_{2}$ & -0.264 & -0.263 & -0.286 & -0.295 & -0.327 & - \\
\hline \multirow[t]{7}{*}{ AquaMet ${ }^{\mathrm{TM}}$} & $\mathrm{Ru}$ & -0.250 & -0.157 & -0.336 & -0.263 & -0.282 & -0.179 \\
\hline & $\mathrm{Ru}=\mathrm{C}_{\text {ylidene }}(1)$ & -0.009 & -0.034 & 0.046 & -0.171 & -0.445 & - \\
\hline & $\mathrm{Ru}=\mathrm{C}_{\text {ylidene }}(2)$ & - & - & -0.427 & -0.333 & -0.148 & -0.210 \\
\hline & $\mathrm{C}_{\mathrm{NHC}}$ & 0.489 & 0.508 & 0.463 & 0.486 & 0.464 & - \\
\hline & $\mathrm{O}$ & -0.475 & -0.531 & -0.530 & -0.546 & -0.546 & - \\
\hline & $\mathrm{Cl}_{1}$ & -0.261 & -0.245 & -0.294 & -0.305 & -0.294 & - \\
\hline & $\mathrm{Cl}_{2}$ & -0.273 & -0.269 & -0.291 & -0.312 & -0.309 & - \\
\hline
\end{tabular}

To check if the MOF has any role in terms of energetics or nature of the reaction intermediates (see Figure 4 to see how the olefin metathesis catalyst interacts with the MOF), $\mathrm{CP} 2 \mathrm{~K}$ calculations were performed. To point out that the MOF was truncated (see Figure 1b), and the anionic MOF moiety was coupled with the ammonium NHC-tagged olefin metathesis catalyst MOF-AquaMet ${ }^{\mathrm{TM}}$ (displayed in Scheme 1c) without the chloride. The binding energy for the Precat was $63.8 \mathrm{kcal} / \mathrm{mol}$ between both ionic moieties. In particular, the sulfonate of the MOF and the ammonium group are linked by a series of $\mathrm{H}$-bonds. Table 5 collects the relative energies, collected in gas phase since calculations by CP2K were performed without explicit solvent molecules. The different nature of the calculations with both computational packages (CP2K and Gaussian), despite significant absolute energies, shows results that qualitatively agree, and are very close in terms of electronic energies. Particularly, among the results with $\mathrm{CP} 2 \mathrm{~K}$, the introduction of the MOF model, instead of the chloride counteranion, involves a flattening of the potential energy surface. Interestingly, both coordination intermediates (Ci1 and Ci2) are especially stabilized, while the metallacycle is relatively less stable, which would favor olefin metathesis [79]. 


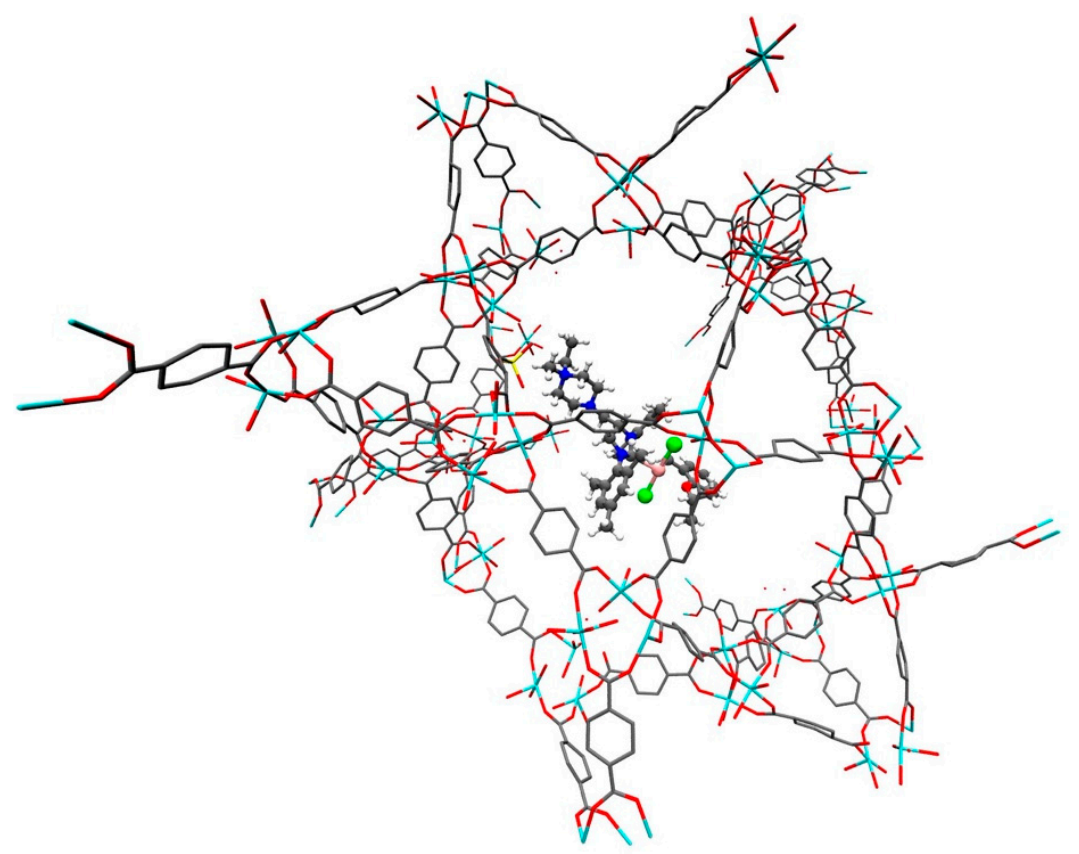

Figure 4. Snapshot of the MOF from the X-Ray with an inserted ammonium NHC-tagged olefin metathesis catalyst AquaMet ${ }^{\mathrm{TM}}$ in a cavity.

Table 5. Relative energies in gas phase (in kcal/mol) of the intermediates for catalysts $\mathrm{HOV}$, AquaMet ${ }^{\mathrm{TM}}$ and MOF-AquaMet ${ }^{\mathrm{TM}}$, and including the model of MOF.

\begin{tabular}{ccccccc}
\hline Model Catalyst & Precat & Act & Ci1 & MCy & Ci2 & I14e \\
\hline AquaMet $^{\mathrm{TM}+(\mathrm{a})}$ & 0.0 & 13.2 & 6.3 & 0.2 & 12.9 & 18.0 \\
AquaMet $^{\mathrm{TM}(\mathrm{a})}$ & 0.0 & 11.8 & 5.2 & -2.4 & 13.1 & 13.2 \\
MOF-AquaMet $^{\mathrm{TM}(\mathrm{a})}$ & 0.0 & 2.1 & -3.1 & 3.1 & 3.9 & 8.2 \\
AquaMet $^{\mathrm{TM}+(\mathrm{b})}$ & 0.0 & 13.6 & 6.0 & 1.0 & 7.0 & 14.4 \\
AquaMet $^{\mathrm{TM}}$ (b) & 0.0 & 14.7 & 5.8 & -0.1 & 9.9 & 10.8 \\
HOV $^{(\mathrm{b})}$ & 0.0 & 12.9 & 5.6 & 0.5 & 10.4 & 13.0 \\
HOV $^{(\mathrm{b}, \mathrm{c})}$ & 0.0 & 10.5 & $15.0(18.7)$ & $11.6(15.4)$ & $20.0(23.8)$ & $9.8(9.0)$ \\
\hline
\end{tabular}

(a) calculated by CP2K; ${ }^{(b)}$ calculated by Gaussian (in parentheses values calculated without the correction of Martin, at $1 \mathrm{~atm}) ;{ }^{(c)}$ Gibbs free energies in gas phase.

To see if the ammonium-tagged catalysts change their catalytic properties for structural reasons in presence of the MOF around, or if the entry of a substrate is prevented, especially when the metal catalyst is confined inside the MOF, steric maps were made around the metal [80]. In the first sphere, at $3.5 \AA$, this is where reactivity takes place [81,82]. If a ligand marks the reactivity by ruthenium complexes, this reaction is the effect caused by the NHC ligand. Consequently, the study was performed with all the catalysts studied here. To determine this steric hindrance around the metal [83], topographical steric maps of NHC ligands were obtained by SambVca 2.1 [84], developed by Cavallo and co-workers. The radius of the sphere around the metal centre was set to $3.5 \AA$, whereas for the atoms we adopted the Bondi radii scaled by 1.17 , and a mesh of $0.1 \AA$ was used to scan the sphere for buried voxels [85]. As reported for the interaction of small molecules with carbo-benzenes [86], the study was extended to higher ranks (i.e., 5.0, 8.0, 10.0, 12.0 and $15.0 \AA$ ). The elucidation of the steric maps, together with the total and quadrant $\% \mathrm{~V}_{\text {Bur }}$ values, give quantitative and qualitative data to predict the reactivity of the metal catalysts. These two-dimensional isocontours represent the interaction surface as topographic maps. Even though the NHC ligand affects up to $12-13 \AA$, its interaction is basically in the first $3.5 \AA$ length around the metal (see Figure 5b) [87]. However, here we had to check how the MOF could sterically take part in the region around the metal where the olefin enters. From Table 6 it is clear that the MOF alone has no significant participation till a range of 
12.0-15.0 $\AA$ (see Figure 5c,d), which confirms that the catalysis inside the MOF is the same as outside the MOF for the Ru-based olefin metathesis catalyst. The $\% \mathrm{~V}_{\text {Bur }}$ and steric maps including all the atoms, with or without the MOF, are quite similar around the metal (see Supplementary Information for further details). On the other hand, the ammonium-tagged catalyst AquaMet ${ }^{\mathrm{TM}}$ is as sterically demanding as $\mathrm{HOV}$, with almost null differences.

(a)

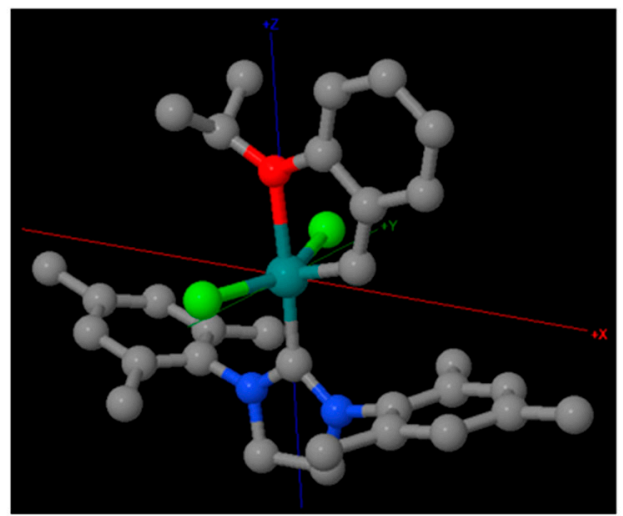

(b)

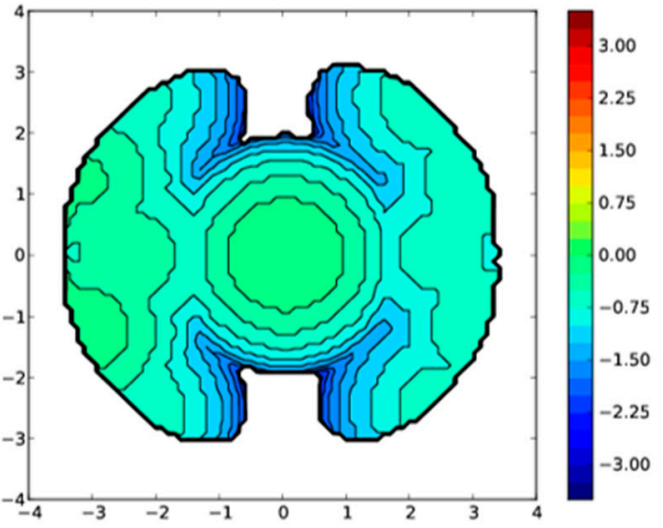

(c)

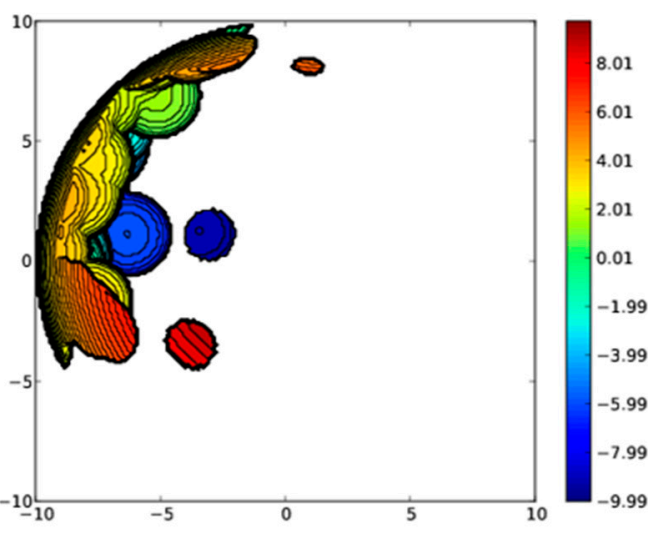

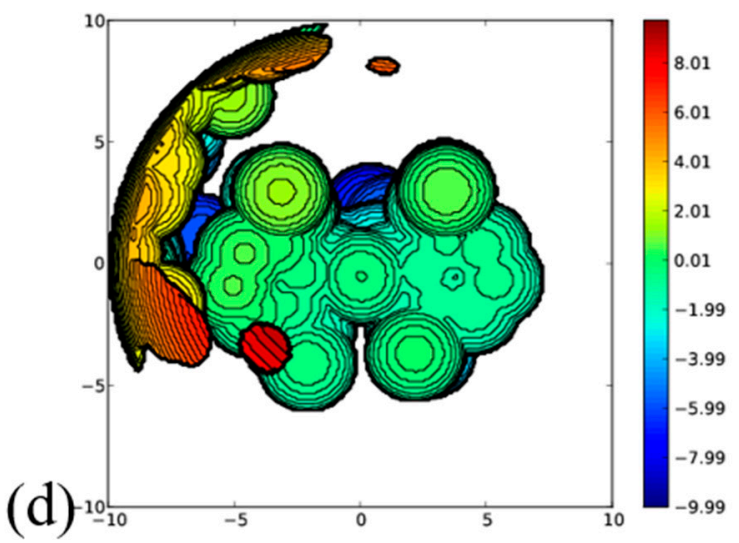

Figure 5. Topographic steric maps of the section of the MOF (plane xy) from the X-ray: (a) orientation of the axis; (b) HOV with a radius of $3.5 \AA$; (c) MOF with a radius of $10 \AA$ and (d) MOF-AquaMet ${ }^{\mathrm{TM}}$ with a radius of $10 \AA$. The linking $\mathrm{C}$ atom of the NHC is on the $\mathrm{z}$ axis, and the metal atom is $2 \AA$ below the plane described by the metal and both chloride atoms. The isocontour curves of the steric maps are given in $\AA$.

Table 6. $\% \mathrm{~V}_{\mathrm{Bur}}$ for catalysts $\mathrm{HOV}$, AquaMet ${ }^{\mathrm{TM}}$, MOF and MOF-AquaMet ${ }^{\mathrm{TM}}$, calculated at radius 3.5, 5.0, 8.0, 10.0, 12.0 and $15.0 \AA$.

\begin{tabular}{ccccccc}
\hline Model Catalyst | Radius & $\mathbf{3 . 5}$ & $\mathbf{5 . 0}$ & $\mathbf{8 . 0}$ & $\mathbf{1 0 . 0}$ & $\mathbf{1 2 . 0}$ & $\mathbf{1 5 . 0}$ \\
\hline HOV & 33.1 & 35.4 & 16.6 & 8.7 & 5.0 & 0.0 \\
AquaMet $^{\mathrm{TM}}$ & 33.3 & 35.6 & 18.7 & 11.0 & 7.1 & 3.7 \\
MOF $_{\text {MOF-AquaMet }}^{\mathrm{TM}}$ & 0.0 & 0.0 & 0.9 & 5.0 & 10.2 & 16.9 \\
& 32.9 & 39.6 & 24.8 & 18.4 & 18.6 & 21.3 \\
\hline
\end{tabular}

Due to the low covalent character presented by the interactions between the metal catalyst and the MOF, we computed the NCI plots using the NCIPLOT package of Contreras-Garcia and co-workers $[88,89]$. The NCI plots allow to observe and qualitatively evaluate the strength of the non-covalent interactions between different moieties, pointing out that they are not available for pseudopotential. This did not represent an issue since the nature of the metal, ruthenium, is not that 
affected by relativistic effects $[90,91]$. Figure 6 shows the NCI plot obtained for Precat. Qualitatively we did not notice any significant difference with respect to the other NCI plots (see Table S1).

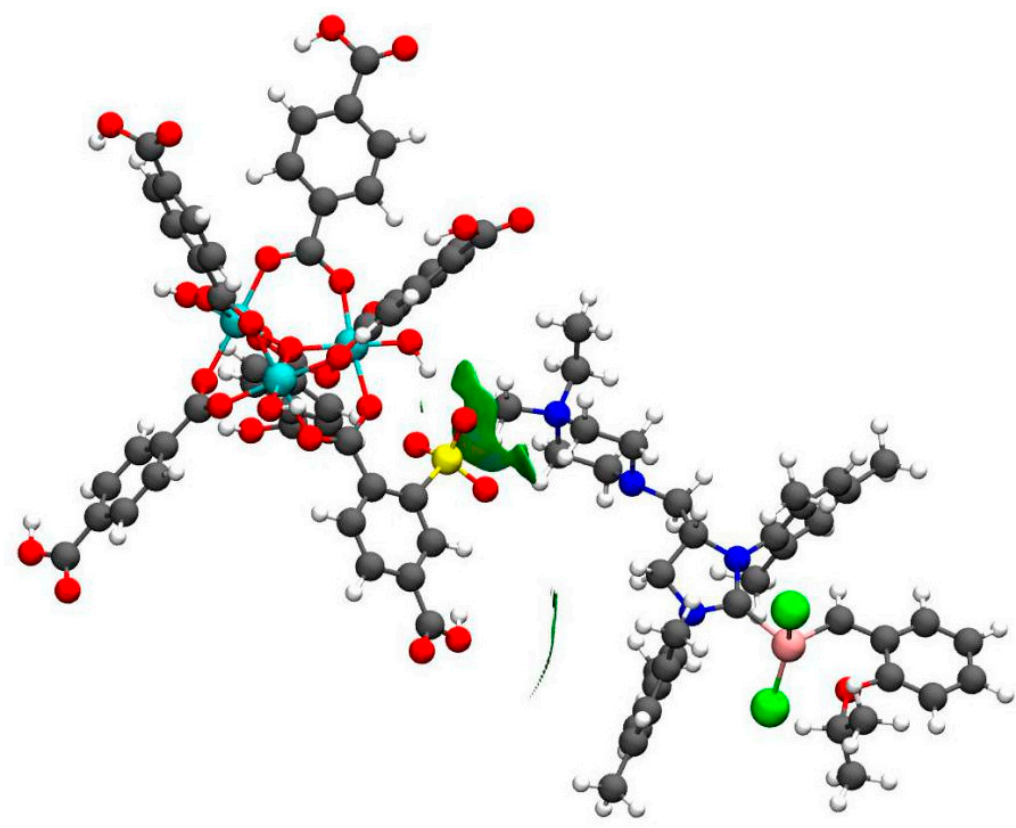

Figure 6. NCI plot of the truncated MOF in combination with Precat.

In the representations, we plotted the isocontour obtained for a value of 0.5 on the reduced density gradient; and for the colour scale, we used the interval from -0.5 to 0.5 of the second density Hessian eigenvalue, going from blue (attractive) to red (repulsive). From a qualitative point of view, we only observed a rather strong interaction between the model of the MOF and the cationic moiety on the backbone of the NHC ligand, defined by a clear H-bond between an oxygen of the anionic sulfonate and the ending $\mathrm{H}$ atom of the cationic chain on the backbone of the NHC ligand $(\mathrm{O} \cdots \mathrm{H}=2.178 \AA$ ). Other relevant interactions came from the hydroxyl of a carboxylic chemical group and the closest isopropyl of the NHC ligand. However, the intensity is rather low in agreement with the weak H-bond among them $(\mathrm{O} \cdots \mathrm{H}=4.389 \AA)$.

\section{Conclusions}

When starting a computational project, the aim is always to achieve challenging objectives, that at an experimental level were not possible with the second-generation Hoveyda-Grubbs catalyst studied here, or that could not be explained as a whole or part. The research group of Grela studied catalytic activity on olefin metathesis [26] confined within a MOF and managed to find an explanation that is both humble and simple, and in line with the results on capsules by Reek and collaborators [92]. Anchoring the catalyst within the MOF is intended to be almost like a heterogeneous catalyst, and to prevent undesired decomposition reactions. Computationally, the results are somewhat similar, with a slight destabilization of the metallacycle that helps to get better catalytic performance [79]. The cationic moiety on the backbone of the NHC is unveiled to positively affect the kinetics, with roughly $2 \mathrm{kcal} / \mathrm{mol}$ of stabilization. Despite not finding big differences, we observed that the confinement of the catalysts enhances their catalytic capacity [26]; this could be a result of avoiding the decomposition of olefin metathesis by means of the interaction of two metal moieties [71]. Thus, either we find a vaccine (i.e., a modification of the catalysts to minimize or remove the decomposition reactions) or the MOFs here are a perfect vaccine for this issue. Overall this study confirms that the NHC-tagged catalysts perform better for the Brönsted acid nature, but the enhancement of the reactivity is also due to the confinement of the ruthenium catalyst inside a cavity of the MOF, blocking the potential decomposition of the metal catalyst. 


\section{Computational Details}

All DFT calculations were performed using the Gaussian09 set of programs [93]. In these calculations, the BP86 of Becke and Perdew was employed [94,95]. The electronic configuration of the studied molecules was described with the standard split valence basis set with a polarization function for $\mathrm{H}, \mathrm{C}, \mathrm{Cl}, \mathrm{N}$ and $\mathrm{O}$ (Def2SVP keyword in Gaussian) of Ahlrichs and co-workers [96]. The quasi relativistic, small-core, effective core potential of Stuttgart/Dresden, with an associated valence basis set (SDD keyword in Gaussian) was used for Ru atom [97].

Solvent effects on the potential energy surfaces of the oligomerization cycle were estimated based on the polarizable continuum solvation model (PCM) using dimethyl carbonate (DMC) as solvent [98,99], the B3LYP, hybrid GGA functional of Becke-Lee, Parr, and Yang [100] and triple- $\zeta$ basis set (cc-pVTZ keyword in Gaussian) [101], together with the Grimme D3 correction term for the electronic energy [102]. Thus, the free energies discussed throughout the manuscript include the electronic energies in solvent that are corrected by the thermal corrections calculated in the gas phase at $\mathrm{T}=323.15 \mathrm{~K}$ and $\mathrm{P}=1354 \mathrm{~atm}[72]$.

The unit cell of Mil-101 is excessively large for periodic DFT calculations, therefore, we performed the calculations on a fragmented cluster of the MOF (Figure 1). All the simulations of the cluster were performed with CP2K [103] at density functional level of theory. The semi-local PBE functional of Perdew, Burke and Ernzerhof was adopted [104] using the DZVP-MOLOPT-SR-GTH Gaussian basis set for all the atom types [105], and a cutoff of 450 Ry for the plane wave auxiliary basis set. Atom positions were optimised converging the force up to $5 \times 10^{-3}$ a.u. and the electronic structure up to $1 \times 10^{-3}$ a.u. The cubic simulation box size was set to $25 \times 25 \times 25 \AA^{3}$ ensuring isolated molecule simulation.

Supplementary Materials: The following are available online at http://www.mdpi.com/2073-4344/10/6/687/s1, xyz coordinates and absolute energies of all computed species; extended steric maps and NCI plots.

Author Contributions: A.P. conceived and designed the experiments. G.P., D.T. and A.P. have run calculations, analyzed data and contributed to writing the manuscript. All authors have read and agreed to the published version of the manuscript.

Funding: This research was funded by the Ministerio de Economía y Competitividad (MINECO) of Spain for project PGC2018-097722-B-I00, the Generalitat de Catalunya for project 2017SGR39, and computer resources and technical support were provided by the Barcelona Supercomputing Center (BSC).

Acknowledgments: A.P. is a Serra Húnter Professor and thanks ICREA for the ICREA Academia Prize 2019. The work was performed under the Project HPC-EUROPA3 (HPC17O1XXP), with the support of the EC Research Innovation Action under the H2020 Programme. G.P. gratefully acknowledges the support of Institut de Química Computacional i Catàlisis (IQCC) and the computer resources and technical support provided by the Barcelona Supercomputing Center (BSC) and the Irish Centre for High-End Computing (ICHEC).

Conflicts of Interest: The authors declare no conflict of interest.

\section{References}

1. Sytniczuk, A.; Forcher, G.; Grotjahn, D.B.; Grela, K. Sequential alkene isomerization and ring-closing metathesis in production of Macrocyclic Musks from biomass. Chem. Eur. J. 2018, 24, 10403-10408. [CrossRef] [PubMed]

2. Rouen, M.; Queval, P.; Borré, E.; Falivene, L.; Poater, A.; Berthod, M.; Hugues, F.; Cavallo, L.; Baslé, O.; Olivier-Bourbigou, H.; et al. Selective metathesis of $\alpha$-olefins from bio-sourced Fischer-Tropsch feeds. ACS Catal. 2016, 6, 7970-7976. [CrossRef]

3. Sytniczuk, A.; Dabrowski, M.; Banach, L.; Urban, M.; Czarnocka-Śniadała, S.; Milewski, M.; Kajetanowicz, A.; Grela, K. At long last: Olefin metathesis macrocyclization at high concentration. J. Am. Chem. Soc. 2018, 140, 8895-8901. [CrossRef] [PubMed]

4. Grubbs, R.H. Handbook of Olefin Metathesis; Wiley-VCH: Weinheim, Germany, 2003.

5. Samojłowicz, C.; Bieniek, M.; Grela, K. Ruthenium-based olefin metathesis catalysts bearing N-Heterocyclic Carbene Ligands. Chem. Rev. 2009, 109, 3708-3742. [CrossRef] [PubMed]

6. Vougioukalakis, G.C.; Grubbs, R.H. Ruthenium-based heterocyclic carbene-coordinated olefin metathesis catalysts. Chem. Rev. 2010, 110, 1746-1787. [CrossRef] 
7. Ogba, O.M.; Warner, N.C.; O'Leary, D.J.; Grubbs, R.H. Recent advances in ruthenium-based olefin metathesis. Chem. Soc. Rev. 2019, 47, 4510-4544. [CrossRef]

8. Poater, A.; Cavallo, L. A Comprehensive study of olefin metathesis catalyzed by Ru-based catalysts. Beilstein J. Org. Chem. 2015, 11, 1767-1780. [CrossRef]

9. Grela, K.; Kajetanowicz, A. Progress in metathesis chemistry. Beilstein J. Org. Chem. 2019, 15, $2765-2766$. [CrossRef]

10. Bailey, G.A.; Foscato, M.; Higman, C.S.; Day, C.; Jensen, V.R.; Fogg, D.E. Bimolecular coupling as a vector for decomposition of fast-initiating olefin metathesis catalysts. J. Am. Chem. Soc. 2018, 140, 6931-6944. [CrossRef]

11. Van Rensburg, W.J.; Steynberg, P.J.; Meyer, W.H.; Kirk, M.M.; Forman, G.S. DFT Prediction and experimental observation of substrate-induced catalyst decomposition in ruthenium-catalyzed olefin metathesis. J. Am. Chem. Soc. 2004, 126, 14332-14333. [CrossRef]

12. Poater, A.; Bahri-Laleh, N.; Cavallo, L. Rationalizing current strategies to protect n-heterocyclic Carbene-based ruthenium catalysts active in olefin metathesis from C-H (De)Activation. Chem. Commun. 2011, 47, 6674-6676. [CrossRef] [PubMed]

13. Manzini, S.; Poater, A.; Nelson, D.J.; Cavallo, L.; Slawin, A.M.Z.; Nolan, S.P. Insights into the decomposition of olefin metathesis pre-catalysts. Angew. Chem. Int. Ed. 2014, 53, 8995-8999. [CrossRef] [PubMed]

14. Pump, E.; Poater, A.; Bahri-Laleh, N.; Credendino, R.; Serra, L.; Scarano, V.; Cavallo, L. Regio, Stereo and chemoselectivity of 2nd generation grubbs ruthenium-catalyzed olefin metathesis. Catal. Today 2020, in press. [CrossRef]

15. Ahmed, T.S.; Montgomery, T.P.; Grubbs, R.H. Using stereoretention for the synthesis of E-Macrocycles with ruthenium-based olefin metathesis catalysts. Chem. Sci. 2018, 9, 3580-3583. [CrossRef] [PubMed]

16. Nechmad, N.B.; Phatake, R.; Ivry, E.; Poater, A.; Lemcoff, N. Unprecedented selectivity of ruthenium iodide Benzylidenes in olefin metathesis reactions. Angew. Chem. Int. Ed. 2020, 59, 3539-3543. [CrossRef] [PubMed]

17. Jana, A.; Grela, K. Forged and fashioned for faithfulness-Ruthenium olefin metathesis catalysts bearing ammonium tags. Chem. Commun. 2018, 54, 122-139. [CrossRef]

18. Mauduit, M.; Schmid, T.E.; Dumas, A.; Colombel-Rouen, S.; Crévisy, C.; Baslé, O. From environmentally friendly reusable ionic-tagged ruthenium-based complexes to industrially relevant homogeneous catalysts: Toward a sustainable olefin metathesis. Synlett 2017, 28, 773-798. [CrossRef]

19. Patrzałek, M.; Piątkowski, J.; Kajetanowicz, A.; Grela, K. Anion metathesis in facile preparation of olefin metathesis catalysts bearing a quaternary ammonium chloride tag. Synlett 2019, 30, 1981-1987. [CrossRef]

20. Kluciar, M.; Grela, K.; Mauduit, M. Ruthenium-based complexes containing a benzimidazolium tag covalently connected to n-heterocyclic Carbene ligands: Environmentally friendly catalysts for olefin metathesis transformations. Dalton Trans. 2013, 42, 7354-7358. [CrossRef]

21. Szczepaniak, G.; Kosiński, K.; Grela, K. Towards "cleaner" olefin metathesis: Tailoring the NHC ligand of second generation ruthenium catalysts to afford auxiliary traits. Green Chem. 2014, 16, 4474-4492. [CrossRef]

22. Skowerski, K.; Białecki, J.; Czarnocki, S.J.; Żukowska, K.; Grela, K. Effective immobilisation of a metathesis catalyst bearing an ammonium-tagged NHC ligand on various solid supports. Beilstein J. Org. Chem. 2016, 12, 5-15. [CrossRef] [PubMed]

23. Skowerski, K.; Szczepaniak, G.; Wierzbicka, C.; Gułajski, L.; Bieniek, M.; Grela, K. Highly active catalysts for olefin metathesis in water. Catal. Sci. Technol. 2012, 2, 2424-2427. [CrossRef]

24. Chołuj, A.; Zieliński, A.; Grela, K.; Chmielewski, M.J. Metathesis@MOF: Simple and robust immobilization of olefin metathesis catalysts inside (Al)MIL-101-NH $\mathrm{NH}_{2}$. ACS Catal. 2016, 6, 6343-6349. [CrossRef]

25. Espallargas, G.M.; Coronado, E. Magnetic functionalities in MOFs: From the framework to the pore. Chem. Soc. Rev. 2018, 47, 533-557. [CrossRef] [PubMed]

26. Chołuj, A.; Karczykowski, R.; Chmielewski, M.J. Simple and robust immobilization of a ruthenium olefin metathesis catalyst inside MOFs by acid-base reaction. Organometallics 2019, 38, 3392-3396. [CrossRef]

27. Chołuj, A.; Krzesiński, P.; Ruszczyńska, A.; Bulska, E.; Kajetanowicz, A.; Grela, K. Noncovalent immobilization of cationic ruthenium complex in a metal-Organic framework by ion exchange leading to a heterogeneous olefin metathesis catalyst for use in green solvents. Organometallics 2019, 38, 3397-3405. [CrossRef]

28. Chołuj, A.; Nogaś, W.; Patrzałek, M.; Krzesiński, P.; Chmielewski, M.J.; Kajetanowicz, A.; Grela, K. Preparation of ruthenium olefin metathesis catalysts immobilized on MOF, SBA-15, and 13X for probing heterogeneous boomerang effect. Catalysts 2020, 10, 438. [CrossRef] 
29. Slugovc, C.; Perner, B.; Stelzer, F.; Mereiter, K. "Second generation" ruthenium carbene complexes with a cis-Dichloro arrangement. Organometallics 2004, 23, 3622-3626. [CrossRef]

30. Ung, T.; Hejl, A.; Grubbs, R.H.; Schrodi, Y. Latent ruthenium olefin metathesis catalysts that contain an N-Heterocyclic carbene ligand. Organometallics 2004, 23, 5399-5401. [CrossRef]

31. Vehlow, K.; Gessler, S.; Blechert, S. Deactivation of ruthenium olefin metathesis catalysts through intramolecular Carbene-Arene bond formation. Angew. Chem. Int. Ed. 2007, 46, 8082-8085. [CrossRef]

32. Romero, P.E.; Piers, W.; McDonald, R. Rapidly initiating ruthenium olefin-metathesis catalysts. Angew. Chem. Int. Ed. 2004, 43, 6161-6165. [CrossRef] [PubMed]

33. Romero, P.E.; Piers, W. Direct observation of a 14-Electron ruthenacyclobutane relevant to olefin metathesis. J. Am. Chem. Soc. 2005, 127, 5032-5033. [CrossRef] [PubMed]

34. Wenzel, A.G.; Grubbs, R.H. Ruthenium metallacycles derived from 14-Electron complexes. New insights into olefin metathesis intermediates. J. Am. Chem. Soc. 2006, 128, 16048-16049. [CrossRef] [PubMed]

35. van der Eide, E.F.; Romero, P.E.; Piers, W. Generation and spectroscopic characterization of ruthenacyclobutane and ruthenium olefin carbene intermediates relevant to ring closing metathesis catalysis. J. Am. Chem. Soc. 2008, 130, 4485-4491. [CrossRef]

36. Vorfalt, T.; Leuthäußer, S.; Plenio, $\mathrm{H}$. An $\left[(\mathrm{NHC})\left(\mathrm{NHC}_{\mathrm{EWG}}\right) \mathrm{RuCl}_{2}(\mathrm{CHPh})\right]$ complex for the efficient formation of sterically hindered olefins by ring-closing metathesis. Angew. Chem. Int. Ed. 2009, 48, 5191-5194. [CrossRef]

37. Huang, J.; Stevens, E.D.; Nolan, S.P.; Petersen, J.L. Olefin metathesis-active ruthenium complexes bearing a nucleophilic Carbene Ligand. J. Am. Chem. Soc. 1999, 121, 2674-2678. [CrossRef]

38. Weskamp, T.; Kohl, F.J.; Hieringer, W.; Gleich, D.; Herrmann, W.A. Highly active ruthenium catalysts for olefin metathesis: The synergy of N-Heterocyclic Carbenes and Coordinatively labile ligands. Angew. Chem. Int. Ed. 1999, 38, 2416-2419. [CrossRef]

39. Grubbs, R.H.; Burk, P.L.; Carr, D.D. Mechanism of the olefin metathesis reaction. J. Am. Chem. Soc. 1975, 97, 3265-3267. [CrossRef]

40. Sanford, M.S.; Love, J.A.; Grubbs, R.H. Mechanism and activity of ruthenium olefin metathesis catalysts. J. Am. Chem. Soc. 2001, 123, 6543-6554. [CrossRef]

41. Conrad, J.C.; Parnas, H.H.; Snelgrove, J.L.; Fogg, D.E. Highly efficient Ru-Pseudohalide catalysts for olefin metathesis. J. Am. Chem. Soc. 2005, 127, 11882-11883. [CrossRef]

42. Manzini, S.; Urbina-Blanco, C.A.; Nelson, D.; Poater, A.; Lebl, T.; Meiries, S.; Slawin, A.M.Z.; Falivene, L.; Cavallo, L.; Nolan, S.P. Evaluation of an olefin metathesis pre-catalyst with a bulky and electron-rich N-heterocyclic carbene. J. Organomet. Chem. 2015, 780, 43-48. [CrossRef]

43. Małecki, P.; Gajda, K.; Gajda, R.; Woźniak, K.; Trzaskowski, B.; Kajetanowicz, A.; Grela, K. Specialized ruthenium olefin metathesis catalysts bearing bulky unsymmetrical NHC ligands: Computations, synthesis, and application. ACS Catal. 2018, 9, 587-598. [CrossRef]

44. Vyboishchikov, S.; Bühl, M.; Thiel, W. Mechanism of olefin metathesis with catalysis by ruthenium carbene complexes: Density functional studies on model systems. Chem. Eur. J. 2002, 8, 3962-3975. [CrossRef]

45. Occhipinti, G.; Bjørsvik, H.-R.; Jensen, V.R. Quantitative structure-activity relationships of ruthenium catalysts for olefin metathesis. J. Am. Chem. Soc. 2006, 128, 6952-6964. [CrossRef]

46. Ben-Asuly, A.; Aharoni, A.; Diesendruck, C.E.; Vidavsky, Y.; Goldberg, I.; Straub, B.F.; Lemcoff, N. Photoactivation of ruthenium olefin metathesis initiators. Organometallics 2009, 28, 4652-4655. [CrossRef]

47. Benitez, D.; Tkatchouk, E.; Goddard, W.A., III. Relevance of cis- and trans-dichloride Ru intermediates in grubbs-ii olefin metathesis catalysis $\left(\mathrm{H}_{2} \mathrm{IMesCl}_{2} \mathrm{Ru}=\mathrm{CHR}\right)$. Chem. Commun. 2008, 6194-6196. [CrossRef]

48. Correa, A.; Cavallo, L. The elusive mechanism of olefin metathesis promoted by (NHC)Ru-Based Catalysts: A trade between steric, electronic, and solvent effects. J. Am. Chem. Soc. 2006, 128, 13352-13353. [CrossRef]

49. Barbasiewicz, M.; Szadkowska, A.; Bujok, R.; Grela, K. Structure and activity peculiarities of ruthenium quinoline and quinoxaline complexes: Novel metathesis catalysts. Organometallics 2006, 25, 3599-3604. [CrossRef]

50. Benítez, D.; Goddard, W.A. The isomerization equilibrium between Cis and trans chloride ruthenium olefin metathesis catalysts from quantum mechanics calculations. J. Am. Chem. Soc. 2005, 127, 12218-12219. [CrossRef]

51. Cavallo, L. Mechanism of ruthenium-catalyzed olefin metathesis reactions from a theoretical perspective. J. Am. Chem. Soc. 2002, 124, 8965-8973. [CrossRef] 
52. Adlhart, C.; Chen, P. Ligand rotation distinguishes first- and second-generation ruthenium metathesis catalysts. Angew. Chem. Int. Ed. 2002, 41, 4484-4487. [CrossRef]

53. Adlhart, C.; Chen, P. Mechanism and activity of ruthenium olefin metathesis catalysts: The role of ligands and substrates from a theoretical perspective. J. Am. Chem. Soc. 2004, 126, 3496-3510. [CrossRef] [PubMed]

54. Stewart, I.C.; Benítez, D.; O’Leary, D.J.; Tkatchouk, E.; Day, M.W.; Goddard,W.A.; Grubbs, R.H. Conformations of N-Heterocyclic carbene ligands in ruthenium complexes relevant to olefin metathesis. J. Am. Chem. Soc. 2009, 131, 1931-1938. [CrossRef] [PubMed]

55. Voccia, M.; Nolan, S.P.; Cavallo, L.; Poater, A. The activity of indenylidene derivatives in olefin metathesis catalysts. Beilstein J. Org. Chem. 2018, 14, 2956-2963. [CrossRef]

56. Yang, H.-C.; Huang, Y.-C.; Lan, Y.; Luh, T.-Y.; Zhao, Y.; Truhlar, D.G. Carbene rotamer switching explains the reverse trans effect in forming the grubbs second-generation olefin metathesis catalyst. Organometallics 2011, 30, 4196-4200. [CrossRef]

57. Zhao, Y.; Truhlar, D.G. Attractive noncovalent interactions in the mechanism of grubbs second-generation Ru catalysts for olefin metathesis. Org. Lett. 2007, 9, 1967-1970. [CrossRef]

58. Poater, A.; Ragone, F.; Correa, A.; Cavallo, L. Comparison of different ruthenium-alkylidene bonds in the activation step with N-Heterocyclic carbene Ru-Catalysts for olefins metathesis. Dalton Trans. 2011, 40, 11066-11069. [CrossRef]

59. Mathew, J.; Koga, N.; Suresh, C.H. C-H Bond activation through $\sigma$-Bond metathesis and agostic interactions: Deactivation pathway of a grubbs second-generation catalyst. Organometallics 2008, 27, 4666-4670. [CrossRef]

60. Fogg, D.E. Introduction to the virtual issue on olefin metathesis-Fundamentals and frontiers. Organometallics 2017, 36, 1881-1883. [CrossRef]

61. Manzini, S.; Nelson, D.J.; Lebl, T.; Poater, A.; Cavallo, L.; Slawin, A.M.Z.; Nolan, S.P. From ruthenium olefin metathesis catalyst to (eta(5)-3-phenylindenyl)hydrido complex via alcoholysis. Chem. Commun. 2014, 50, 2205-2207. [CrossRef]

62. Hong, S.H.; Chlenov, A.; Day, M.W.; Grubbs, R.H. Double C-H Activation of an N-Heterocyclic carbene ligand in a ruthenium olefin metathesis catalyst. Angew. Chem. Int. Ed. 2007, 46, 5148-5151. [CrossRef]

63. Manzini, S.; Urbina-Blanco, C.A.; Poater, A.; Slawin, A.M.Z.; Cavallo, L.; Nolan, S.P. From olefin metathesis catalyst to alcohol racemization catalyst in one step. Angew. Chem. Int. Ed. 2011, 51, 1042-1045. [CrossRef] [PubMed]

64. Poater, A.; Cavallo, L. Mechanistic insights into the double C-H (de)activation route of a Ru-based olefin metathesis catalyst斿. J. Mol. Catal. A Chem. 2010, 324, 75-79. [CrossRef]

65. Jawiczuk, M.; Młodzikowska-Pieńsko, K.; Osella, S.; Trzaskowski, B. Molecular modeling of mechanisms of decomposition of ruthenium metathesis catalysts by acrylonitrile. Organometallics 2020, 39, 239-246. [CrossRef]

66. Webster, C.E. Computational insights into degenerate ethylene exchange with a grubbs-type catalyst. J. Am. Chem. Soc. 2007, 129, 7490-7491. [CrossRef] [PubMed]

67. Stewart, I.C.; Keitz, B.K.; Kuhn, K.M.; Thomas, R.M.; Grubbs, R.H. Nonproductive events in ring-closing metathesis using ruthenium catalysts. J. Am. Chem. Soc. 2010, 132, 8534-8535. [CrossRef]

68. Poater, A.; Vummaleti, S.V.C.; Pump, E.; Cavallo, L. Comparing Ru and Fe-catalyzed olefin metathesis. Dalton Trans. 2014, 43, 11216-11220. [CrossRef]

69. Bantreil, X.; Poater, A.; Urbina-Blanco, C.A.; Bidal, Y.D.; Falivene, L.; Randall, R.A.M.; Cavallo, L.; Slawin, A.M.Z.; Cazin, C.S.J. Synthesis and reactivity of ruthenium phosphite indenylidene complexes. Organometallics 2012, 31, 7415-7426. [CrossRef]

70. Hong, S.H.; Wenzel, A.G.; Salguero, T.T.; Day, M.W.; Grubbs, R.H. Decomposition of ruthenium olefin metathesis catalysts. J. Am. Chem. Soc. 2007, 129, 7961-7968. [CrossRef]

71. Urbina-Blanco, C.A.; Poater, A.; Lebl, T.; Manzini, S.; Slawin, A.M.Z.; Cavallo, L.; Nolan, S.P. The activation mechanism of Ru-Indenylidene complexes in olefin metathesis. J. Am. Chem. Soc. 2013, 135, 7073-7079. [CrossRef]

72. Martin, R.L.; Hay, P.J.; Pratt, L. Hydrolysis of ferric ion in water and conformational equilibrium. J. Phys. Chem. A 1998, 102, 3565-3573. [CrossRef]

73. Poater, A.; Pump, E.; Vummaleti, S.V.C.; Cavallo, L. The right computational recipe for olefin metathesis with ru-based catalysts: The whole mechanism of ring-closing olefin metathesis. J. Chem. Theory Comput. 2014, 10, 4442-4448. [CrossRef] [PubMed] 
74. Nuñez-Zarur, F.; Solans-Monfort, X.; Pleixats, R.; Rodríguez-Santiago, L.; Sodupe, M. DFT study on the recovery of hoveyda-grubbs-type catalyst precursors in enyne and diene ring-closing metathesis. Chem. Eur. J. 2013, 19, 14553-14565. [CrossRef]

75. Tracz, A.; Gawin, A.; Bieniek, M.; Olszewski, T.K.; Skowerski, K. Ammonium NHC-Tagged olefin metathesis catalysts-Influence of counter-ions on catalytic activity. New J. Chem. 2018, 42, 8609-8614. [CrossRef]

76. Parr, R.G.; Szentpály, L.V.; Liu, S. Electrophilicity index. J. Am. Chem. Soc. 1999, 121, 1922-1924. [CrossRef]

77. Geerlings, P.; De Proft, F.; Langenaeker, W. Conceptual density functional theory. Chem. Rev. 2003, 103, 1793-1873. [CrossRef]

78. Koopmans, T. Über die Zuordnung von wellenfunktionen und eigenwerten zu den einzelnen elektronen eines atoms. Physica 1934, 1, 104-113. [CrossRef]

79. Poater, A.; Solans-Monfort, X.; Clot, E.; Copéret, C.; Eisenstein, O. DFT Calculations of d0 M(NR)(CHtBu)(X)(Y) $\left(\mathrm{M}=\mathrm{Mo}, \mathrm{W} . ; \mathrm{R}=\mathrm{CPh}_{3}, 2,6-i \mathrm{Pr}-\mathrm{C}_{6} \mathrm{H}_{3} ; \mathrm{X}\right.$ and $\left.\mathrm{Y}=\mathrm{CH}_{2} t \mathrm{Bu}, \mathrm{OtBu}, \mathrm{OSi}(\mathrm{O} t \mathrm{Bu})_{3}\right)$ olefin metathesis catalysts: Structural, spectroscopic and electronic properties. Dalton Trans. 2006, 2006, 3077-3087. [CrossRef]

80. Falivene, L.; Cao, Z.; Petta, A.; Serra, L.; Poater, A.; Oliva, R.; Scarano, V.; Cavallo, L. Towards the online computer-aided design of catalytic pockets. Nat. Chem. 2019, 11, 872-879. [CrossRef]

81. Poater, A.; Cavallo, L. Comparing families of olefin polymerization precatalysts using the percentage of buried volume. Dalton Trans. 2009, 8875-8883. [CrossRef]

82. Mariz, R.; Poater, A.; Gatti, M.; Drinkel, E.; Bürgi, J.J.; Luan, X.; Blumentritt, S.; Linden, A.; Cavallo, L.; Dorta, R. C2-symmetric chiral disulfoxide ligands in rhodium-catalyzed 1,4-addition: From ligand synthesis to the enantioselection pathway. Chem. Eur. J. 2010, 16, 14335-14347. [CrossRef] [PubMed]

83. Jacobsen, H.; Correa, A.; Poater, A.; Costabile, C.; Cavallo, L. Understanding the M(NHC) (NHC=N-Heterocyclic Carbene) bond. Coord. Chem. Rev. 2009, 253, 687-703. [CrossRef]

84. Falivene, L.; Credendino, R.; Poater, A.; Petta, A.; Serra, L.; Oliva, R.; Scarano, V.; Cavallo, L. SambVca 2. A web tool for analyzing catalytic pockets with topographic steric maps. Organometallics 2016, 35, 2286-2293. [CrossRef]

85. Poater, A.; Cosenza, B.; Correa, A.; Giudice, S.; Ragone, F.; Scarano, V.; Cavallo, L. SambVca: A web application for the calculation of the buried volume of N-heterocyclic carbene ligands. Eur. J. Inorg. Chem. 2009, 2009, 1759-1766. [CrossRef]

86. Turias, F.; Poater, J.; Chauvin, R.; Poater, A. How carbo-benzenes fit molecules in their inner core as do biologic ion carriers? Struct. Chem. 2016, 27, 240-259. [CrossRef]

87. Poater, A.; Falivene, L.; Urbina-Blanco, C.A.; Manzini, S.; Nolan, S.P.; Cavallo, L. How does the addition of steric hindrance to a typical n-heterocyclic carbene ligand affect catalytic activity in olefin metathesis? Dalton Trans. 2013, 42, 7433-7439. [CrossRef]

88. Johnson, E.R.; Keinan, S.; Mori-Sánchez, P.; Contreras-Garcia, J.; Cohen, A.; Yang, W. Revealing noncovalent interactions. J. Am. Chem. Soc. 2010, 132, 6498-6506. [CrossRef]

89. Contreras-Garcia, J.; Johnson, E.R.; Keinan, S.; Chaudret, R.; Piquemal, J.-P.; Beratan, D.N.; Yang, W. NCIPLOT: A program for plotting noncovalent interaction regions. J. Chem. Theory Comput. 2011, 7, 625-632. [CrossRef]

90. Poater, J.; Gimferrer, M.; Poater, A. Covalent and ionic capacity of MOFs to sorb small gas molecules. Inorg. Chem. 2018, 57, 6981-6990. [CrossRef]

91. Masdemont, J.; Luque-Urrutia, J.A.; Gimferrer, M.; Milstein, D.; Poater, A. Mechanism of coupling of alcohols and amines to generate aldimines and $\mathrm{H}_{2}$ by a pincer manganese catalyst. ACS Catal. 2019, 9, 1662-1669. [CrossRef]

92. Jans, A.C.H.; Gómez-Suárez, A.; Nolan, S.P.; Reek, J.N.H. A switchable gold catalyst by encapsulation in a self-assembled cage. Chem. Eur. J. 2016, 22, 14836-14839. [CrossRef] [PubMed]

93. Frisch, M.J.; Trucks, G.W.; Schlegel, H.B.; Scuseria, G.E.; Robb, M.A.; Cheeseman, J.R.; Scalmani, G.; Barone, V.; Mennucci, B.; Petersson, G.A.; et al. Gaussian 09, Revision E.01; Gaussian, Inc.: Wallingford, CT, USA, 2009.

94. Becke, A.D. Density-functional exchange-energy approximation with correct asymptotic behavior. Phys. Rev. A 1988, 38, 3098-3100. [CrossRef] [PubMed]

95. Perdew, J.P. Density-functional approximation for the correlation energy of the inhomogeneous electron gas. Phys. Rev. B 1986, 33, 8822-8824. [CrossRef] [PubMed]

96. Schäfer, A.; Horn, H.; Ahlrichs, R. Fully optimized contracted gaussian basis sets for atoms Li to Kr. J. Chem. Phys. 1992, 97, 2571-2577. [CrossRef] 
97. Küchle, W.; Dolg, M.; Stoll, H.; Preuss, H. Energy-adjusted pseudopotentials for the actinides. Parameter sets and test calculations for thorium and thorium monoxide. J. Chem. Phys. 1994, 100, 7535-7542. [CrossRef]

98. Barone, V.; Cossi, M. Quantum calculation of molecular energies and energy gradients in solution by a conductor solvent model. J. Phys. Chem. A 1998, 102, 1995-2001. [CrossRef]

99. Tomasi, J.; Persico, M. Molecular interactions in solution: An overview of methods based on continuous distributions of the solvent. Chem. Rev. 1994, 94, 2027-2094. [CrossRef]

100. Perdew, J.P.; Burke, K.; Ernzerhof, M. Generalized gradient approximation made simple. Phys. Rev. Lett. 1996, 77, 3865-3868. [CrossRef] [PubMed]

101. Kendall, R.A.; Dunning, T.H., Jr.; Harrison, R.J. Electron affinities of the first-row atoms revisited. Systematic basis sets and wave functions. J. Chem. Phys. 1992, 96, 6796-6806. [CrossRef]

102. Grimme, S.; Antony, J.; Ehrlich, S.; Krieg, H. A aonsistent and accurate Ab Initio parametrization of density functional dispersion correction (DFT-D) for the 94 elements H-Pu. J. Chem. Phys. 2010, 132, 154104. [CrossRef] [PubMed]

103. Hutter, J.; Iannuzzi, M.; Schiffmann, F.; Vandevondele, J. cp2k: Atomistic simulations of condensed matter systems. Wiley Interdiscip. Rev. Comput. Mol. Sci. 2014, 4, 15-25. [CrossRef]

104. Perdew, J.P.; Ruzsinszky, A.; Csonka, G.I.; Vydrov, O.A.; Scuseria, G.E.; Constantin, L.A.; Zhou, X.; Burke, K. Restoring the density-gradient expansion for exchange in solids and surfaces. Phys. Rev. Lett. 2007, 100, 136406. [CrossRef] [PubMed]

105. Vandevondele, J.; Hutter, J. Gaussian basis sets for accurate calculations on molecular systems in gas and condensed phases. J. Chem. Phys. 2007, 127, 114105. [CrossRef] [PubMed]

(C) 2020 by the authors. Licensee MDPI, Basel, Switzerland. This article is an open access article distributed under the terms and conditions of the Creative Commons Attribution (CC BY) license (http://creativecommons.org/licenses/by/4.0/). 